\title{
The 1835 Williams College Expedition to Maine, New Brunswick and Nova Scotia: the First Geological Field Trip by a North American College
}

\author{
Howard J. Falcon-Lang \\ Department of Earth Sciences, Royal Holloway, University of London, Egham, Surrey TW20 0EX, UK \\ $<$ h.falcon-lang@es.rhul.ac.uk>
}

Date received: 01 May 2009 Date accepted: 29 June 2009

\begin{abstract}
The first known geological excursion by a North American college was conducted in 1835 . Twenty staff and students belonging to Williams College - a liberal arts college in Massachusetts, USA - explored the geology bordering the Bay of Fundy in northeast Maine, New Brunswick and Nova Scotia. Led by two young professors of natural history, Ebenezer Emmons and Albert Hopkins, the party made extensive observations around Pasammaquoddy Bay, Saint John, Parrsboro, and Windsor, as well as more widely through the Minas and Cumberland basins. Although partly following in the footsteps of two pioneering Bostonians, Charles Jackson and Francis Alger, who had reconnoitred the region in the late 1820s, the Williams College party nevertheless made several original observations. One of most important was a study of the anatomy and paleoclimatic significance of permineralized plants from Joggins and Grindstone Island undertaken by Emmons. This was only the second study of its kind worldwide and later inspired William Dawson to do similar work. Largely overlooked by historians of geology, the Williams College expedition, which comprised a four-week voyage of about $1800 \mathrm{~km}$, illustrates well the challenges and opportunities of geological field work in the early Nineteenth Century.
\end{abstract}

\section{RÉSUMÉ}

La première excursion géologique connue d'un collège nord-américain a été réalisée en 1835 . Vingt membres du personnel et étudiants du Collège Williams - collège d'arts libéraux du Massachusetts, Etats-Unis - ont exploré la géologie des bords de la baie de Fundy dans le nord-est du Maine, au Nouveau-Brunswick et en Nouvelle-Écosse. Le groupe dirigé par deux jeunes professeurs d'histoire naturelle, Ebenezer Emmons et Albert Hopkins, a effectué de nombreuses observations dans les environs de la baie de Passamaquoddy, de Saint-Jean, de Parrsboro et de Windsor, ainsi que dans des secteurs plus étendus à l'intérieur des bassins Minas et Cumberland. Même si le groupe du Collège Williams a en partie suivi les pas de deux pionniers de Boston, Charles Jackson et Francis Alger, qui avaient effectué une reconnaissance de la région vers la fin des années 1820 , il a néanmoins fait plusieurs observations originales. L'une des plus importantes a été l'étude de l'anatomie et de l'importance paléoclimatique des végétaux minéralisés de Joggins et de l'île Grindstone réalisée par Emmons. Il s'agissait seulement de la deuxième étude du genre à l'échelle mondiale; elle a ultérieurement inspiré Williams Dawson à exécuter des travaux similaires. Largement négligée par les historiens de géologie, l'expédition du Collège Williams, qui a comporté un voyage de quatre semaines d'environ 1800 kilomètres, illustre bien les défis et les possibilités qui s'offraient dans le domaine des travaux géologiques sur le terrain au début du $19^{\mathrm{e}}$ siècle.

[Traduit par la redaction]

\section{INTRODUCTION}

The Canadian Maritime Provinces are world renowned for their geology, spectacularly displayed along more than 3000 $\mathrm{km}$ of coastal section (Atlantic Geoscience Society 2001). A favourite destination for geology students, it has a growing reputation for geotourism (Bennett 2007) and, since July 2008, Nova Scotia boasts a UNESCO World Heritage Site at the Joggins Fossil Cliffs (Falcon-Lang 2008). Also, plans are afoot for a UNESCO Geopark in the Saint John area of New
Brunswick(Miller 2008). However, few people realize just what a long tradition of geoeducation and geotourism exists in the Maritimes. The aim of this paper is to describe the first college field trip to study the geology of the Bay of Fundy, some 175 years ago: the Williams College excursion of 1835 (Hopkins 1835a, b; Emmons 1836; Perry 1899). This important expedition is little known, and received only brief mention in the exhaustive Bicentennial History of Williams College (Lewis 1993).

Williams College is a prestigious liberal arts college founded 

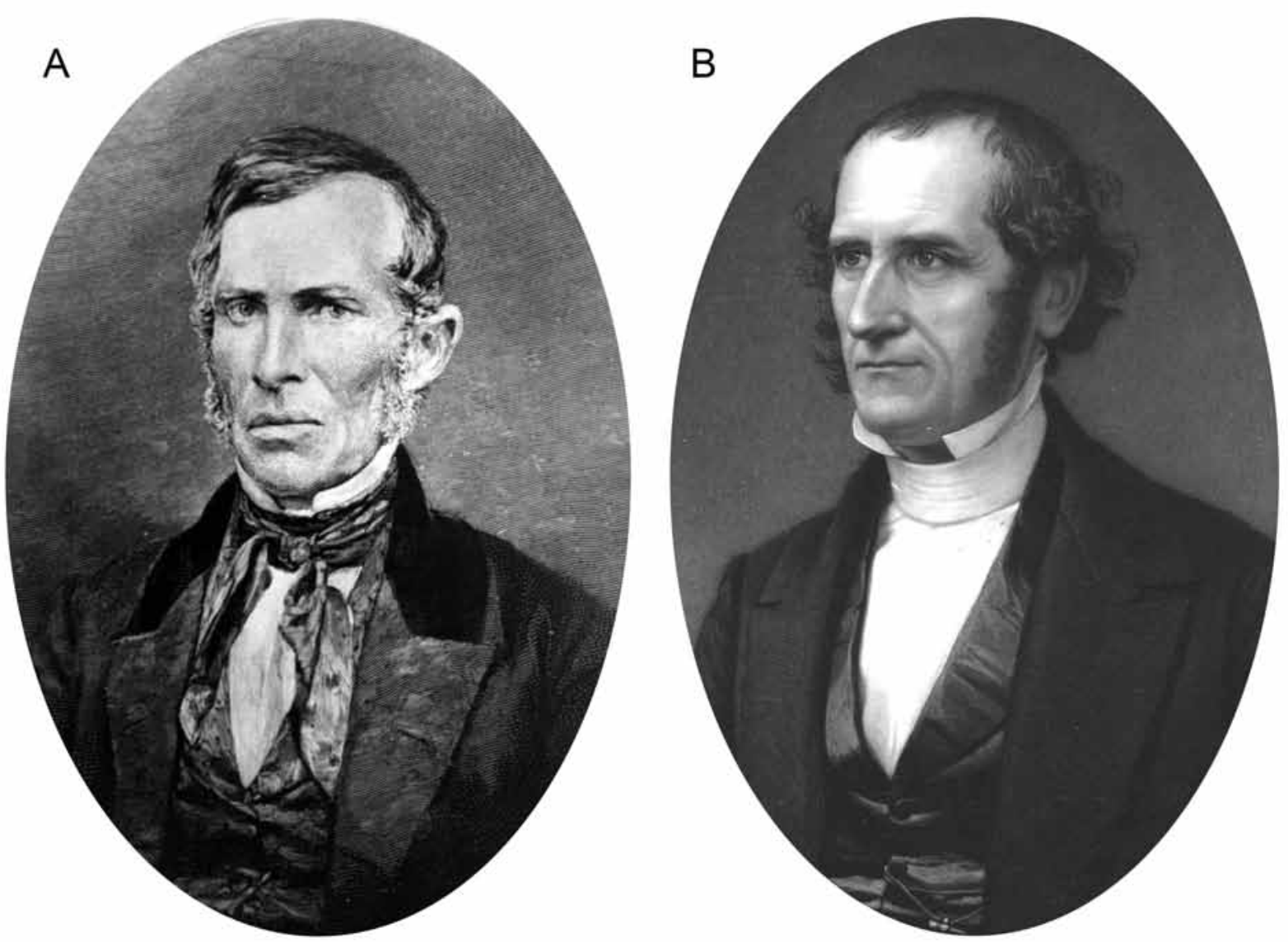

Fig. 1. The field trip leaders, (A) Ebenezer Emmons (1799-1863) from a daguerreotype produced about 1850, and (B) Albert Hopkins (1807-1872) from a daguerreotype produced in 1856. Both images reproduced by kind permission of Williams College Archives and Special Collections, Williamstown, Mass., USA.

in 1793 in Berkshire County, Massachusetts, USA (Durfee 1860). It is notable in the United States as one of the first colleges to devote significant attention to the natural sciences alongside the classical curriculum (Smallwood 1937). A major early scientific influence on the syllabus was Amos Eaton (1776-1847), a polymath who made remarkable contributions to American botany and geology and later advised on the construction of the Erie Canal (McAllister 1941). Eaton taught for only one year at Williams College, in 1817, but during his short tenure he reportedly inspired an "uncontrollable enthusiasm" for botany and mineralogy amongst students and faculty alike (Fenton 1969). That zeal was expressed by the foundation, in 1825, of a Linnean Society at the College (Anon. 1852).

The appointment of two young professors in the late $1820 \mathrm{~s}$ further strengthened the teaching of natural sciences at the college (Fig. 1). The first of these appointees was Ebenezer Emmons (1799-1863) - himself a Williams graduate (1818) who went on to study natural science under Eaton at Rensselaer Polytechnic Institute in Troy, New York State (1824-1826). Emmons joined the faculty at Williams College in 1828 and became Professor of Chemistry and Natural Sciences in 1833, a post he held until 1860 (Wells and Davies 1847). At the time of the field excursion described herein (1835), he also held a joint appointment at the Rensselaer Polytechnic Institute.
Although still a young man, Emmons was already recognized as one of the most eminent geologists in the United States (Durfee 1860). Emmons is best remembered for his pioneering work unravelling the Lower Paleozoic stratigraphy of North America, and in particular his Taconic System, proposed in 1842, but later shown to be time-equivalent to the lower part of Sedgewick's Cambrian System, and disused. In addition, he named the Adirondack Mountains in 1838 and Taconic Mountains in 1846 (Friedman 2006). The second appointee was Albert Hopkins (1807-1872), another Williams graduate (1826) and a keen astronomer, who became Professor of Mathematics and Natural Sciences in 1829, and founded the first observatory at Williams College in 1835 (Durfee 1860). Both Emmons and Hopkins played a major role in the instigation of the field trip to Maritime Canada.

\section{ORIGINS OF THE EXCURSION TO MARITIME CANADA}

The geological excursion to Maritime Canada in 1835 was an important early event in the history of Williams College. Believed to be the first scientific expedition of its kind out of any North American college, it attracted significant atten- 
tion from educational establishments as far afield as Europe (Rogers 1855). As Paul Chadbourne (1823-1883), a former President of Williams College, commented at Hopkins' funeral in 1872, "such expeditions are comparatively common now, when travel is easy and the necessity of field work in natural history is well understood. But that such an expedition should have been planned in a college among the Berkshire Hills, and successfully carried out nearly forty years ago, when as yet it was necessary to travel a hundred miles to reach the railroad" is a remarkable achievement (Chadbourne 1877, p. 32).

The origin of the field trip appears to have been closely linked to a series of religious revivals that took place at the Protestant Williams College in the early 1830s (Perry 1899). Growing out of a conviction that God spoke through two books, Scripture and Nature, the college's Linnean Society, which had become somewhat moribund in earlier years, was redeveloped with new vigour (Wells and Davies 1847). On 2 April 1835, the group was rebranded as a secret society - Phi Beta Theta, an acronym for Phusis Biblos Theou, or "Nature, the Book of God" (Anon. 1885) - but in a matter of months became a public society, the Lyceum of Natural History (Ruldoph 1957). The aim of the Lyceum, which remained an influential organization at Williams College for the next 50 years, was to promote "the Natural Sciences, and the prosecution of antiquarian researches" (Anon. 1915, p. 7).

During its turbulent early months, the Lyceum met every two weeks in East College, one of the buildings of Williams College, constructed in 1798, to discuss science and natural history (Smallwood 1937; Fig. 2). At one meeting in the summer term of 1835, reports of the geology and mineralogy of Maritime Canada (Jackson and Alger 1828, 1829, 1832) were read and discussed with great excitement (Hopkins 1835a). The authors of those reports, Charles T. Jackson (1802-1880) and Francis Alger (1807-1863), were young scientists from nearby Boston (Wolfe 2007), and the students of the Lyceum instantly adopted them as role models. Thus, it came as no surprise to the faculty that just a few days later, "it became evident that [the students] would be satisfied with nothing short of an excursion" to see the geological curiosities of Maritime Canada for themselves and experience the legendary tides of the Bay of Fundy (Hopkins 1835a, p. 445).

At a subsequent meeting on 27 June 1835, Emmons and the student president of the Lyceum, Thompson Kidder (18121887), were appointed "to ascertain the probable cost of such an expedition" (Smallwood 1937, p. 555). The money for financing the trip was to be largely secured from honorary members and outside friends, though the college and individual students were expected to contribute. After only a short time, the logistics were finalized. Captain Bangs Hallett (1807-1893) of Yarmouth, Massachusetts, a Cape Cod sea captain in the merchant service (Anon. 1982) and his sloop, the Flight, were engaged to undertake the journey (Emmons 1836). Due to the constraints of term time, the expedition was to be limited to "an absence of about four weeks on shipboard and among the Blue Noses of the northeast” (Perry 1899, p. 566).

Participants on the trip numbered "twenty individuals,

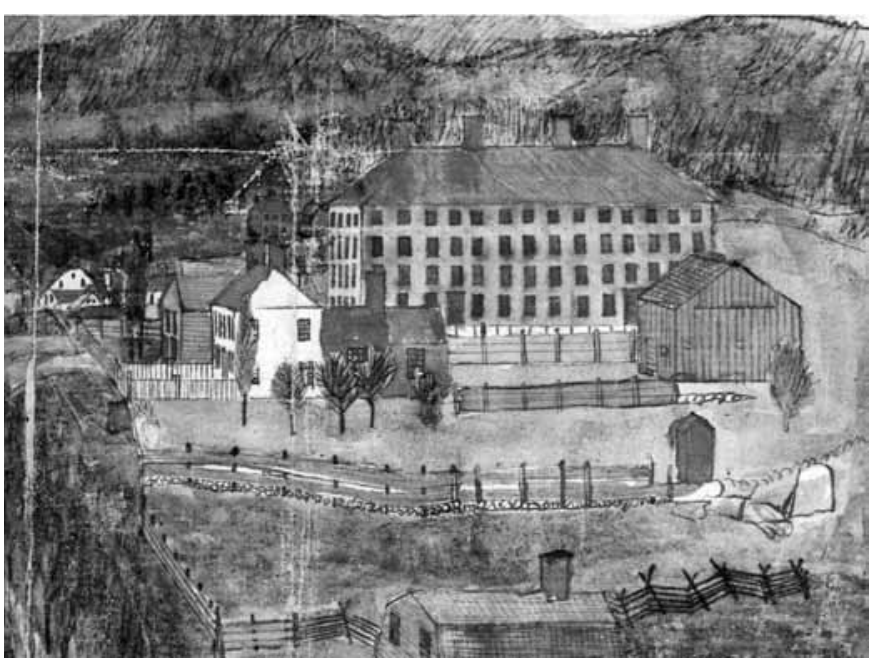

Fig. 2. East College (part of Williams College), which comprised the first home of the Lyceum of Natural History until the fire of 1841. Anonymous (American) water color painting entitled "A part of the easterly view of Williamstown from the fourth story of Old College" dating from the period, 1798-1828. Reproduced with kind permission of Williams College Museum of Art, Williamstown, Mass., USA. Gift of the Watkinson Library, Trinity College, Hartford, Connecticut, through the efforts of Don Engley.

most of whom had been affected by the [religious] awakening" earlier in the year, and part of the impetus for the trip seems to have been to grow the faith of the group as they journeyed together (Hopkins 1835a). "Indeed", commented Hopkins, "had it not been for the awakening, I question whether the expedition would have moved at this time" at all (Perry 1899, p. 566). In addition to Emmons and Hopkins, the other staff member involved was Simeon Calhoun (1804-1876), a college tutor who later pursued a calling with the American Bible Society (Wosh 1994). Most of the rest were undergraduate students, except, "two or three in the party who cared little or nothing about [natural history], but who joined it at [Hopkins'] invitation for the purpose of health and recreation. One of these was Mr B.F. Mather, a merchant of Williamstown" (Perry 1899, p. 568).

In devising the itinerary for the trip, it is almost certain that Emmons and Hopkins had some personal contact with Charles Jackson. Jackson had spent the summer of 1835 reconnoitring the geology of northeast coastal Maine, and the Williams College itinerary included all of his sites - despite the fact that they were not published until four years later (Jackson 1839). A personal connection with Jackson, although not substantiated, is quite plausible given the small size of the scientific community in the eastern United States at that time. Jackson had helped found the influential Boston Society of Natural History in 1830 (Johnson 2004), so perhaps he was asked for advice when the Lyceum of Natural History was instigated at Williams College in 1835 (Smallwood 1937). Certainly Emmons main- 


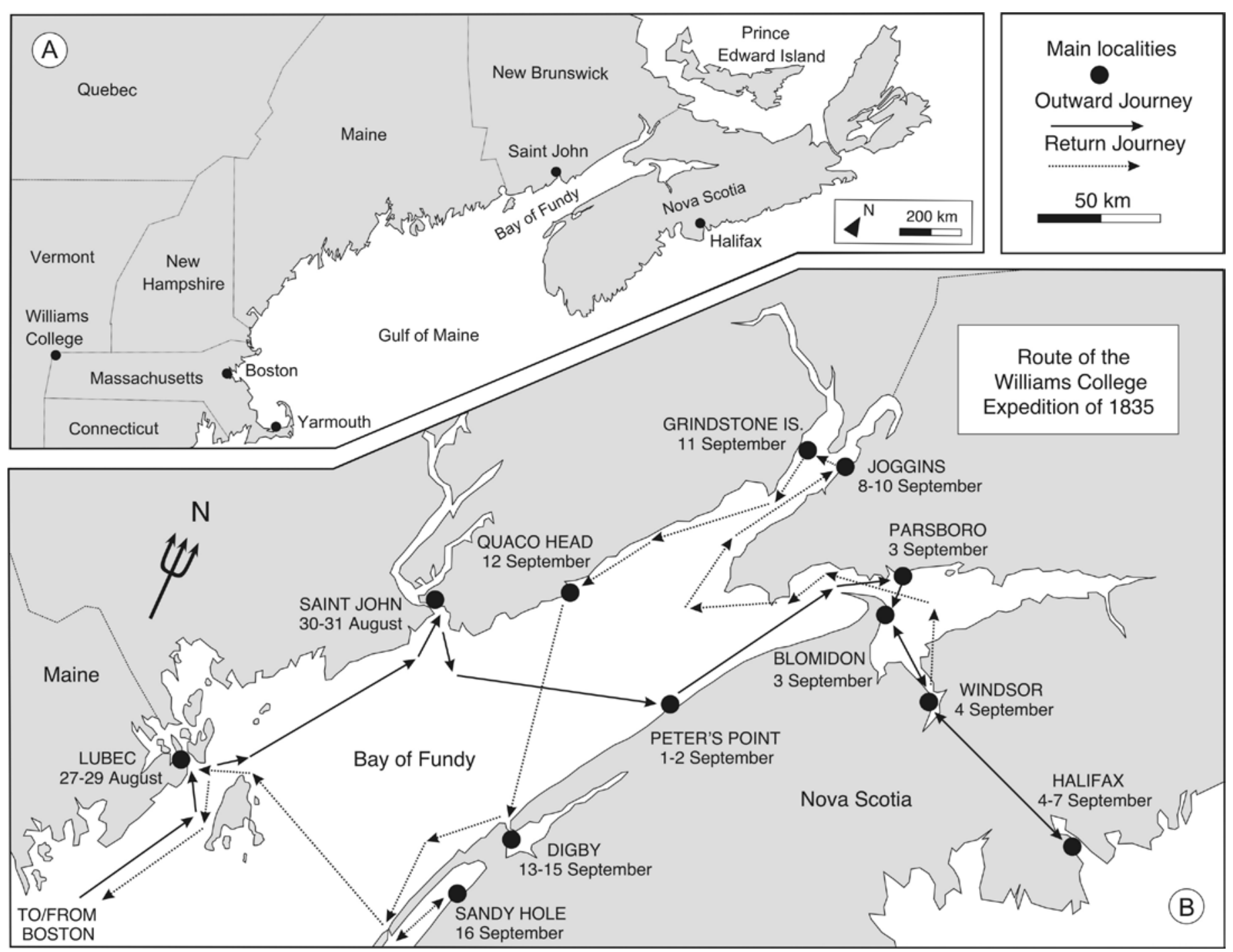

Fig. 3. Map of the Williams College Expedition of 1835. (A) Eastern North America, showing location of Williams College in northwest Massachusetts, Boston, the port of departure, Yarmouth, the harbour where the Flight was based, and Maritime Canada, (B) Detail of the journey through the Bay of Fundy (see text for explanation).

tained a close relationship with Jackson in subsequent years (Wolfe 2007).

In describing the Williams College excursion of 1835, the following account is based on a combination of independent sources. Hopkins published a detailed narrative, combined with extracts from the journals of unidentified student participants, in the 19 October 1835 edition of the Boston magazine Monthly Traveller (Hopkins 1835a). He also published a variant of his journal in three successive numbers of the bi-weekly American Traveller, another Boston magazine, on 13, 17 and 20 November 1835 (Hopkins 1835b). Arthur Latham Perry (1830-1905), Professor of History and Economics at Williams College from 1853-1891, additionally published a useful commentary on Hopkins' account, more than 60 years after the event (Perry 1899). Lastly, Emmons published his own independent account, supplemented by microscopic analysis of his fossil collections, in the spring-1836 edition of Silliman's American Journal of Science (Emmons 1836). Other records, and most specimens from the 1835 expedition, were lost to a fire in East College in 1841, where the library and museum of the society were located in Room 24 (Anon. 1885).

\section{AN EDUCATION IN QUODDY BAY}

After a long overland journey, the excursion properly commenced on Tuesday 25 August 1835, the Flight sailing out of Boston in the early evening (Fig. 3). An uneventful voyage of forty hours soon brought them to the disputed international border between Maine and New Brunswick on the morning of Thursday 27 August (Hopkins, 1835a). The border was informally marked by the West Quoddy Lighthouse, constructed in 1808, and with the aid of a pilot vessel, Captain Hallett successfully navigated through thick fog to safe harbour at Lubec $\left(44^{\circ} 51^{\prime} 33 \mathrm{~N}, 66^{\circ} 59^{\prime} 11 \mathrm{~W}\right)$. A local saying at that time stated that "no man's education is complete until he has been 
in Quoddy Bay" (Hopkins 1835a, p. 446). In part to test thi saying, in part due to the impediment of thick fog, and in par on the recommendation of Charles Jackson, who had visite the area earlier in the summer, the group decided to tarry day and explore the geology of these uncharted borderlands

The next morning, Friday 28 August, travelling by rou ing boat, some of the party visited a nearby "plaster mill $\left(44^{\circ} 51^{\prime} 30 \mathrm{~N}, 67^{\circ} 01^{\prime} 01 \mathrm{~W}\right)$, a kilometre west of Lubec. Th mill was located on a 100-m-wide isthmus between two bay: through which a deep channel (canal) had been excavated $t$ harness the power of the 9-m tides (Hopkins 1835a). At hig tide, water was allowed to pour into a 100-acre pond. Aroun low tide the sluice gate was opened and this body of wate drained down slope into the adjacent bay, generating sufficier energy to grind 100 tons of gypsum per day (referred to as plaster in Hopkins 1835a). All the gypsum (plaster) was imported from the British territories to the north (Mellen 1843) and a couple of weeks later the group was scheduled to visit one of the gypsum mines at Windsor, Nova Scotia, from which it was extracted (Emmons 1836). The sheer magnitude of this trade was emphasized by General Charles Peavey of Eastport (17871854), who indicated that in the previous year (1834) alone some 1800 ships, each carrying about 100 tons of gypsum from Nova Scotia and New Brunswick, had passed through the port (Hopkins 1835a). The principal use of gypsum in the early Nineteenth Century was to create smooth internal wall surfaces and decorative mouldings. After being ground, the gypsum $\left(\mathrm{CaSO}_{4} \cdot \mathrm{H}_{2} \mathrm{O}\right)$ was heated to drive out water of crystalization, creating anhydrite $\left(\mathrm{CaSO}_{4}\right)$, and then re-hydrated, resulting in a malleable form of gypsum (plaster) that hardened over time. This latter process would have taken place near the site of ultimate usage, rather than at the Lubec "plaster mill".

Of especial interest at Lubec was the geological succession exposed in the mill cutting, or canal (Fig. 4). This comprised "stiff, marly clay" containing extant species of marine "molluscous animals", which Emmons (1836) regarded as part of the "newer Tertiary", unconformably resting on top of "greenstone" (p. 381). More recent research shows that these superficial deposits belong to the Late Pleistocene Presumpscot Formation, a marine deposit dated at 12-13 ka (Dorion et al. 2001). However, Emmons (1836) was not far wrong with his age determination because the term "newer Tertiary" specifically referred to rocks later assigned to the Pliocene (Adam 1857).

As the deposits lay "forty feet above high water", Emmons (1836, p. 381) reasoned that the coastline had undergone significant uplift over "extensive territories" in fairly recent times. This was a bold hypothesis. The concept that tectonism had caused relative sea level change during Recent and historic times had only just been proposed by Lyell in his Principles of Geology (1830-1833). In contrast to earlier catastrophist assertions, this theory recognized sea level as a uniformitarian phenomenon, which, argued Emmons (1836), was "not infrequent in our day" (p. 381). Of course, Emmons' conclusions about the Lubec canal section were only partly correct in the light of modern understanding. The Presumpscot Formation

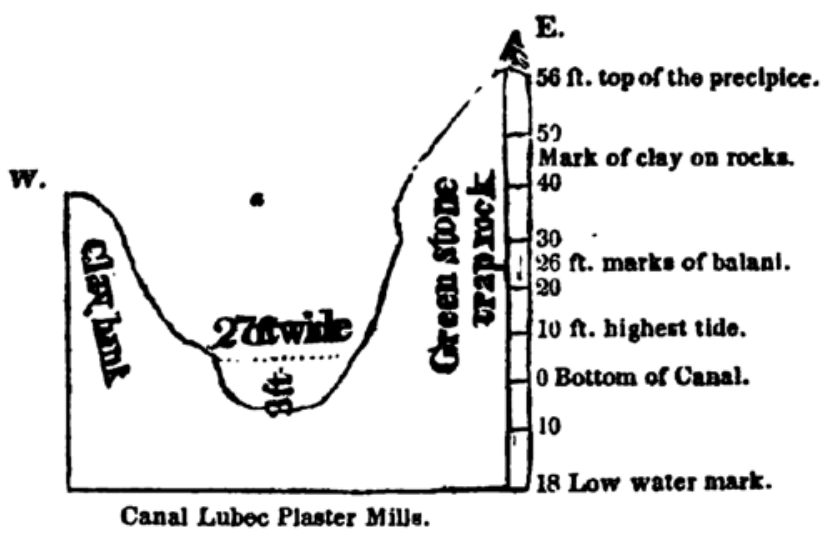

- This whole ravine was filled with mud and marine shells.

Fig. 4. Section exposed in the cutting (canal) at the "plaster mill”, near Lubec, Maine (after Jackson 1839, p. 20). The western side consists of a "Clay bank" of Presumpscot Formation (Pleistocene) while the eastern side consist of "Greenstone trap rock" (Silurian-Devonian Edmunds Formation). The figure illustrates how at high tide, the canal is filled $3 \mathrm{ft}$ deep, thereby feeding a large pond, whose carefully controlled outflow drove the plaster mills. "Mark of clay on rocks" at $\mathbf{4 0}$ feet above sea level indicates maximum elevation of marine Presumpscot Formation.

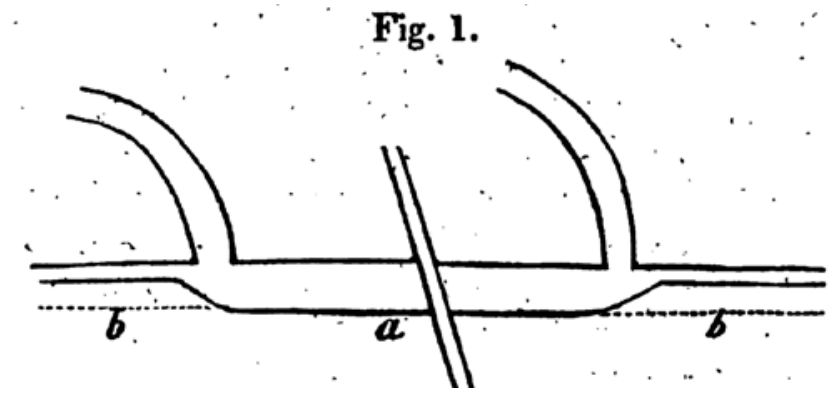

Fig. 5. Dykes in the Silurian Edmunds Formation, near Lubec, Maine (after Emmons 1836, p. 332), showing two phases of intrusion $(a, b)$.

formed by coastal drowning due to post-glacial sea level rise during Meltwater Pulse 1A (resulting in the transgression of the DeGeer Sea), an interpretation that relies on the glacioeustatic concept, not developed until the mid-Nineteenth Century (Bertram et al. 1996). Its present elevation above sea level results from isostatic rebound (Fleming et al. 1998).

After a disorientating row through thick fog, the party's next stop was Moose Island, on which Eastport, Maine, was built $\left(44^{\circ} 53^{\prime} 59 \mathrm{~N}, 67^{\circ} 01^{\prime} 02 \mathrm{~W}\right)$. Here the group saw more "greenstone" interbedded with a "transition limestone" and noted lots of "trap dykes" cross-cutting the strata. Based on the geometry of the dykes (Fig. 5), Emmons (1836) speculated that they had been intruded while the limestone was still soft. The stratified rocks at Moose Island belong to the Edmunds Formation of present nomenclature, a Silurian-Devonian suc- 
cession of volcanic pyroclastics, basalts and carbonate intruded by gabbroic dykes and sills (Hon et al. 1992). The volcanic rocks were formed in the Acadian Orogeny during which the Avalon Terrane collided with Laurentia (van Staal et al. 1998). Subsequent work has confirmed Emmons' assertion about the near-contemporaneous nature of the intrusions with the sediments (Gates 1975).

The final site visited was a lead mine, which - Hopkins noted wryly - "was only a short row of eleven miles" from Lubec $\left(44^{\circ} 50^{\prime} 25 \mathrm{~N}, 67^{\circ} 03^{\prime} 05 \mathrm{~W}\right)$. Owned by Solomon Thayer (1789-1857), the tax collector and customs official for Lubec (Anon. 1859), the mine had been opened in 1832. However, it remained relatively little worked due to the death of chief miner in an accident at sea (Jackson 1839). Hopkins (1835a, p. 446) noted that "the lead occurs in veins, which run completely down to the bay; though we traced several of them quite a distance back into the country". To this information Emmons (1836) added that there were three veins in total, each locally thickening to as much as 3-4 ft, and containing sulphides of both lead (galena) and zinc (sphalerite) with some iron.

Although Hopkins and Emmons included few illustrations in their account, Jackson (1839) documented the lead mines in a series of detailed sketches based on his visit a few weeks earlier, in July 1835 (Fig. 6). Jackson, who a short time later in 1836 became first State Geologist of Maine (Hineline 1988), elaborated on the lead-mining practice, stating how "in exploring this vein, a drift or gallery was excavated, in a westerly direction, following the vein in its course. This drift we measured, and found that it extended into the rock, to a distance of 60 feet. A perpendicular shaft or well was sunk into the middle of the gallery, to the depth of 16 feet" (Jackson 1839, p. 22). Just a few years after the visits of Jackson, Hopkins and Emmons, Thayer's lead mines were abandoned due to the collapse of the global lead market, which was the result of overproduction in South America (Rowe 1983).

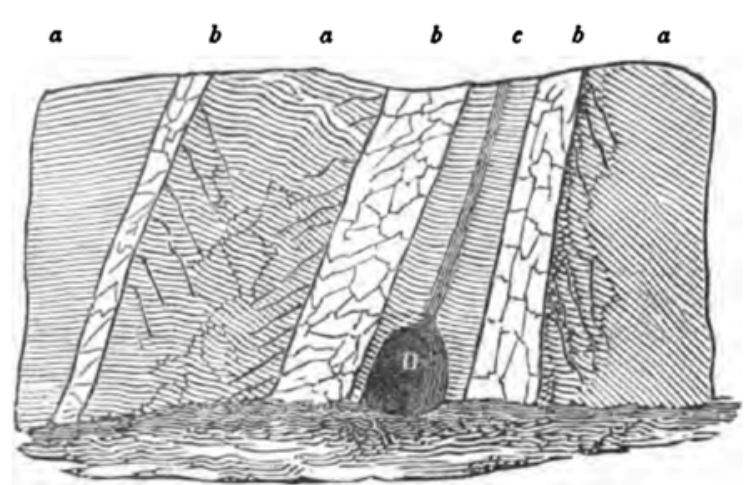

a a a Strata of blue limestone, with veins of calcareous spar near the dykes. $b \quad b \quad b$ Trap dykes.

$c$ Vein of galena.

D Drift.

Fig. 6. Solomon Thayer's lead mine near Lubec, Maine (after Jackson 1839, p. 28).

\section{ON THE ROCKS AT SAINT JOHN}

The following day, Saturday 29 August, the Flight set out eastwards, following the coastline toward Saint John, New Brunswick, under continuing foggy conditions (Emmons 1836 erroneously gave the date as 27 August on p. 383 of his journal). The purpose of the visit was to fulfil regulations at the Custom House there and to take on supplies (Hopkins 1835a). After sheltering overnight in a cove, by the early morning of Sunday 30 August, the party had passed Point Lepreau $\left(45^{\circ} 03^{\prime} 31 \mathrm{~N}\right.$, $66^{\circ} 27^{\prime} 33 \mathrm{~W}$ ) on the coast of southern New Brunswick and, a little later, the Mahogany Islands $\left(45^{\circ} 12^{\prime} 30 \mathrm{~N}, 66^{\circ} 06^{\prime} 29 \mathrm{~W}\right)$, near Saint John, came into view.

At this point, the fog became very dense and visibility dropped to a few tens of metres. Unable to navigate, the captain ordered the sails furled and the ship was allowed to drift backwards. At 9 am, a pilot vessel came alongside to warn of rocks. The Flight had drifted with the tide onto the Musquash Ledges $\left(45^{\circ} 07^{\prime} 33 \mathrm{~N}, 66^{\circ} 15^{\prime} 02 \mathrm{~W}\right)$, some $20 \mathrm{~km}$ southwest of Saint John. By mid-afternoon and following some fervent prayer (and the turning of the tide), the party reached the safety of Saint John Harbour (Hopkins 1835a). It being Sunday, they went their separate ways to attend church services, Hopkins choosing to worship at the Methodist Chapel on Germaine Street, constructed in 1807 (Scobie and Grant 1992).

The next day, Monday 31 August, the group visited Reversing Falls $\left(45^{\circ} 15^{\prime} 34 \mathrm{~N}, 66^{\circ} 05^{\prime} 12 \mathrm{~W}\right)$ at the mouth of the Saint John River, arriving on a falling tide. Of this spectacle, Hopkins (1835a) observed, "as the water below retires back into the ocean, the ripple increases, until, at length the whole accumulated weight, unequipoised, pitches with an amazing fury, through a winding rocky chasm about a quarter of mile in width" (p. 448). The party took the opportunity of sketching the phenomenon, which results from a differential of 6.4 $\mathrm{m}$ between high and low tides in this part of the Bay of Fundy (Miller 2001). At high tide, the elevated level of the bay causes the Saint John River to back-up, a phenomenon that generates "rapids" and is felt up to $100 \mathrm{~km}$ inland, as far as Fredericton. As the tide falls, the direction of flow is reversed, with the "rapids" becoming most marked near low tide.

Regarding the geology of Saint John, Emmons (1836) limited his comments to a few notes on the "greywacke slate, highly inclined" on which the city stood, and the abundant boulders of "granite, gneiss, hornblende and a conglomerate" that were strewn along the coast (p. 383). The rather vague description refers to the Neoproterozoic and Lower Paleozoic bedrock of the Avalon and Gander terranes, whose boundary occurs at Reversing Falls, and various glacial erratics (Miller 2001). Hopkins noted that additional geologizing had had to be abandoned because the "gentleman" who had promised to guide them was unfortunately absent. The identity of this learned gentleman is not revealed, but might have been Robert Foulis (1796-1866), the inventor and naturalist, who had lived in Saint John since the 1820s (Wright and Miller 1990). This idea is supported by the fact that Foulis had ear- 
lier corresponded with Jackson in the course of the latter's excursion, and was a corresponding member of the Boston Society of Natural History, whose membership also included Jackson, Hopkins and Emmons (Warren 1853). Hence, Foulis was known to key members of the excursion.

\section{ZEOLITES AT PETER'S POINT}

On late Monday afternoon, the group departed Saint John, "wind and tide favoring" their passage across the Bay of Fundy to the Minas Basin of Nova Scotia. The thick fog was at last beginning to disperse and by the afternoon of Tuesday 1 September they reached the middle of the Bay of Fundy. Here the party let down bottles and recorded water temperature at different depths. Finding that water at "thirty fathoms" (about $55 \mathrm{~m}$ ) was colder than at the surface, they speculated about the significance of these results for the "central heat theory" of D'Ortous de Mairan (Hopkins 1835a). This theory stated that the Earth had cooled from a molten ball and retained a hot core (Brush 1996). Rather than negating this theory, Hopkins (1835a) thought their observations of downward cooling rather confirmed it since "warmer water, from a well known property of fluids, rises to the surface" (p. 448).

Next morning, Wednesday 2 September, the group awoke to find that "a long wall like barrier of Greenstone, lay close beside" the ship (Hopkins 1835a, p. 449). They had reached Nova Scotia. Describing the geology from onboard ship, Emmons (1836) noted that, "approaching near the shore, we behold a high perpendicular range of dark-colored rocks, fissured and broken, frequently overhanging their bases and apparently without support and ready to fall" (p. 334). With much excitement, the party jumped into rowing boats to investigate, despite Hopkins' attempts to "restrain [the] young men a little" (p. 449). Their location was Peter's Point (or Head), a rocky headland that protruded out into the Bay of Fundy, known today as Margaretsville Point $\left(45^{\circ} 02^{\prime} 58 \mathrm{~N}, 65^{\circ} 03^{\prime} 54 \mathrm{~W}\right)$. The headland was named after the apocryphal tale of Peter Barnes, a wrecker who, in 1793, reputedly lured a schooner to its doom here for ill-gotten gain (McLeod 1891).

In outcrop, Emmons identified two rock types, an "amygdaloid" rock, which was "quite vesicular" and "lava-like" and a "greenstone" rock, which "exhibits more or less tendency to columnar structure" and in hand specimen was "compact, heavy, and sonorous when struck with a hammer" (Emmons 1836, p. 335). Clearly this was reference to the basaltic lavaflows comprising the Margaretsville (amygdaloid) and Brier Island (greenstone) members of the North Mountain Basalt Formation (Kontak 2008); Emmons was to map the basalt formation for 130 miles along the coast of Nova Scotia during the excursion, and to examine its internal stratigraphy and relationship with adjacent sedimentary rocks. At Peter's Point, he also made extensive collections of zeolite minerals, the most abundant, being laumontite, $\mathrm{CaAl}_{2} \mathrm{Si}_{4} \mathrm{O}_{12} \cdot 4 \mathrm{H}_{2} \mathrm{O}$, a white, vitreous zeolite that forms small prismatic crystals.

After feverishly collecting minerals in a sea "cave, roofed and paved with stilbite" (another zeolite, $\mathrm{CaAl}_{2} \mathrm{Si}_{7} \mathrm{O}_{18} .7 \mathrm{H}_{2} \mathrm{O}$, which is common in amygdales and now the provincial mineral of Nova Scotia), Emmons and Hopkins emerged around noon to find that the rest of the party had completely disappeared. One of the students had ventured to the cliff-top where he had met Sir Brenton Halyburton (1775-1860), Chief Justice of Nova Scotia, who had a summer house "which stood just on the brow of the cliff". So, while Emmons and Hopkins had been labouring on the shore, the rest of the party had been enjoying Halyburton's considerable hospitality. Halyburton had built the cottage in 1808 and the fishing community in which it was located was later renamed Margaretsville in honour of his wife. In his later commentary on the trip, Perry (1899, p. 570) mistook Halyburton for T.C. Haliburton, the well known the satirist and Supreme Court Judge, who lived in nearby Windsor at the time of the Williams College excursion.

\section{STRATIGRAPHY OF THE MINAS BASIN}

The tide now favouring departure, the Flight weighed anchor and the following morning, Thursday 3 September, reached "Parsboro, in the basin of mines" (i.e., the Minas Basin). Here the group had "letters to Dr. Gesner, the physician of the place, a gentleman of science who introduced [them] to his cabinet, stored with the richest minerals" (Hopkins 1835a, p. 449). Abraham Pineo Gesner (1797-1864) had trained as a doctor in London, where he had met Charles Lyell and had become interested in geology (Russell 1976). Having settled in Parrsboro in 1827, at the time of the Williams College excursion Gesner was preparing material for his book on the geology and mineralogy of Nova Scotia (Gesner 1836). To a significant degree based on the earlier work of Jackson and Alger (1828, 1829,1832 ), this book proved controversial, the Bostonians accusing Gesner of outright plagiarism (von Bitter 1977, 1978). Gesner's "cabinet" was later to comprise the core of the museum that he founded in 1842 in Saint John (Gesner 1842) - Canada's first public museum (Miller and Buhay 2007). Some the specimens for that collection were obtained from Emmons (Gesner 1842), indicating that the two men remained on friendly terms after the 1835 meeting.

Nevertheless, at the time of the Williams College excursion, Gesner seems to have been somewhat edgy and territorial. During an initial trip to Partridge Island $\left(45^{\circ} 22^{\prime} 02 \mathrm{~N}\right.$, $\left.64^{\circ} 20^{\prime} 04 \mathrm{~W}\right), 4.5 \mathrm{~km}$ south of Parrsboro, where the margin of the North Mountain basalt formed a prominent headland, the group collected more zeolites and spectacular calcite specimens (Fig. 7). However, Hopkins joked somewhat uneasily how they "almost feared an assault from the Dr. [Gesner] for seizing such beautiful specimens on what might be considered rather as his private hunting ground" (Hopkins, 1835a, p. 449). They were evidently not the first to violate Gesner's site, Emmons (1836) noting that due to "the proximity of the village [of Parrsboro], this enchanting spot is much exposed to visits, hence everything that falls from the cliffs is soon carried away" (p. 346). 

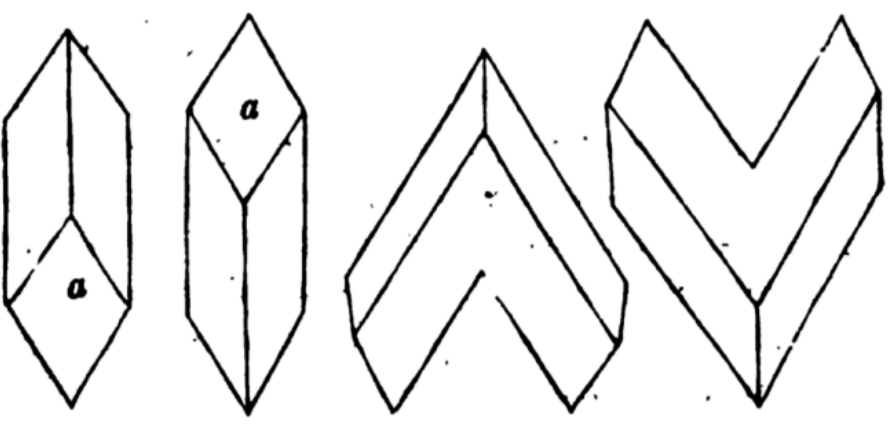

Fig. 7. Diagram of the calcite crystals found on Partridge Island, near Parrsboro (after Emmons 1836, p. 347).

After lunch, the group set out in the Flight, together with Gesner and a few "friends from Parsboro", to study the stratigraphic relationship of the basalt with a succession of red beds they had observed en route to Parrsboro the day before (Hopkins 1835a). First sailing east, they briefly visited Two Islands $\left(45^{\circ} 23^{\prime} 06 \mathrm{~N}, 64^{\circ} 12^{\prime} 49 \mathrm{~W}\right)$, where an impressive sea arch was visible in the basalt. Next they travelled southwest to "Cape Blow me Down" or Blomidon $\left(45^{\circ} 15^{\prime} 50 \mathrm{~N}\right.$, $\left.64^{\circ} 20^{\prime} 08 \mathrm{~W}\right), 13 \mathrm{~km}$ south of Parrsboro on the opposite side of the Minas Basin, a sheer cliff which rose "to a height of about four hundred feet [120 m]" (Emmons 1836, p. 348). Here, Emmons described a thick succession of gypsum-bearing red sandstone, which gently dipped southwest before passing under the basalt that capped the cliff-top. Above the contact with the sandstone, the basalt comprised an "Amydaloid, a greenish rock, abounding in small cavities, and resembling very much the slag of a Furnace" (Hopkins 1835a, p. 450). Sailing northward they drew alongside Cape Split $\left(45^{\circ} 20^{\prime} 04 \mathrm{~N}, 64^{\circ} 29^{\prime} 38 \mathrm{~W}\right)$ and observed the distinctively layered nature of the basalt and the spectacular "needles" produced by wave erosion at the tip of the cape (Fig. 8). There they collected abundant amethysts.

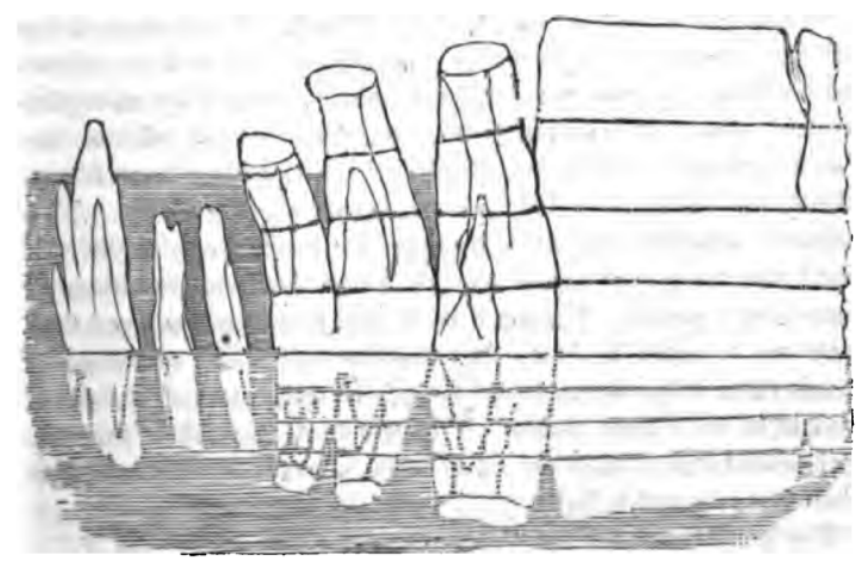

Fig. 8. A drawing of the North Mountain Basalt at Cape Split, Minas Basin, Nova Scotia, done at a high tide (Emmons 1836, p. 337). The shape of this cape has dramatically changed over the past 175 years due to coastal erosion. Height of the needles is probably about $30 \mathrm{~m}$.
In the course of this excursion an argument broke out between Gesner and Emmons about the age of the red sandstone that lay beneath the basalt at Blomidon. Summarizing the matter, Hopkins (1835a, p. 450) wrote that, "we must dissent from an opinion, we think expressed by the Dr. [Gesner] that it is the Old Red - it appears to be the New". Gesner remained unconvinced, however, and reiterated more forcefully his belief that the red sandstone and basalt were older than the Carboniferous coal measures and thus "Old Red" or latest Silurian/Devonian sediments (Gesner 1836, 1843) - a position that later brought him into sharp conflict with Charles Lyell (Gesner 1849). Subsequent work shows that Gesner was in error. The red beds at Blomidon, which comprise semi-arid alluvial deposits and playa evaporites (Mertz and Huebert 1990) are of Late Triassic to earliest Jurassic age (Fowell and Traverse 1995) while the overlying North Mountain basalt is radiometrically dated at $201.27 \pm 0.06 \mathrm{Ma}$, positioned just above the Triassic-Jurassic boundary (Jourdan et al. 2009). The red beds would therefore be time-equivalent to the New Red Sandstone of earlier nomenclature, as Emmons correctly inferred.

\section{WINDSOR AND HALIFAX}

After dropping Gesner and company back at Parrsboro, the Flight set sail for Windsor at the head of the Avon estuary on the south side of the Minas Basin $\left(44^{\circ} 59^{\prime} 07 \mathrm{~N}, 64^{\circ} 08^{\prime} 50 \mathrm{~W}\right)$, arriving on the morning on Friday 4 September. Here the group decided to split in two. One party travelled overland to Halifax, while the other continued to explore the geology of the Minas Basin. The first group, which included Emmons and Hopkins, hired stagecoaches and after "a few hours ride" found themselves at "the head of the Bedford Basin" and a short time after that in Halifax (Hopkins 1835a, p. 450). There, they spent the weekend engaged in tourist activities. They toured the Citadel, which was in the process of being rebuilt, visited Province House on Hollis Street, took a steamer to Dartmouth, enjoying fine views of Halifax, and scoured the farmer's market for interesting bargains. They also called upon the American Consul, who showed them his cabinet of more than "sixty varieties of corals". They returned to Windsor on Monday 7 September, arriving about noon (Hopkins, 1835a).

Meanwhile the other group had a profitable time investigating the local geology around Windsor. Friday and Saturday were spent back at Cape Blomidon, where the party carefully examined the contact of the basalt with the red sandstone and collected more minerals. On Sunday 6 September, seeking somewhere to celebrate the Sabbath, they "rowed ashore, and followed the beach about a mile" south of Cape Blomidon. Eventually, they found a little settlement and spent the day amongst "devoted and spiritual followers of the Lamb" (Hopkins 1835a, p. 452). This was probably the community of Lyons Cove ( $\left.44^{\circ} 15^{\prime} 35 \mathrm{~N}, 64^{\circ} 20^{\prime} 53 \mathrm{~W}\right)$, marked on an 1834 map of Nova Scotia, a mile south of Blomidon (Mackay 1834).

The next morning, Monday 7 September, they visited King's College, Windsor, an Anglican institution founded in 1789 
and conferred university status in 1802 by King George III. Following a fire, King's College was later relocated to Halifax in 1923, where it became closely associated with Dalhousie University (Horn 1999). At the time of the Williams College visit, there were only 4-5 students enrolled, but nevertheless facilities were excellent with a well-stocked library and much valuable physics equipment (Hopkins 1835a). Before rejoining with the party returning from Halifax, there was sufficient time to visit one of the gypsum quarries in the area, working the Mississippian Windsor Group. At this Clifton Quarry, opened in 1828, they observed the "fine crystallized" gypsum and noted how it was "quarried precisely like common lime, though the blasting [was] less expensive, owing to the softness of the mineral" (Hopkins 1835a, p. 453). These quarries were a source of raw material for the "plaster mill" at Lubec, where the Williams College group had called ten days earlier.

Regrouping on the Flight at noon, the party then set sail for their final destinations in the Minas Basin, Spencers Island (45 $\left.19^{\prime} 49 \mathrm{~N}, 64^{\circ} 41^{\prime} 30 \mathrm{~W}\right)$ and Cape d'Or $\left(45^{\circ} 17^{\prime} 24 \mathrm{~N}\right.$, $\left.64^{\circ} 46^{\prime} 26 \mathrm{~W}\right)$. Arriving during mid-afternoon, the party quickly located veins of "native copper" at Cape d'Or associated with "amygdaloid" units of the North Mountain Basalt. However, despite reports of its occurrence "in pieces of two or three pounds weight” (Hopkins, 1835a, p. 453), Emmons noted that it is now "exceedingly scarce, and obtained with difficulty" (Emmons 1836, p. 350). These copper deposits had first been noted by the early French explorer, Samuel de Champlain (1567-1635) in 1607 (Murdoch 1865) but never yielded sufficient ore to be considered of economic value (Dawson 1868).

\section{JOGGINS, JOGGINS!}

The Williams College party had now been travelling for over two weeks and undertaken extensive studies of the North Mountain Basalt and its mineral assemblage. However, as far as the group was concerned, the best part of the trip was yet to come - the Coal Measure cliffs of South Joggin on the south coast of Chignecto Bay, the northern arm of the Bay of Fundy (Fig. 2). "For several days", recalled Hopkins (1835a) on 7 September, "it had been "Joggins, Joggins" - so we were glad to get there" at last (p. 453). That evening, riding an ebb tide in a precise manoeuvre, the Flight was pulled out of the Minas Basin, before being swept up into the Cumberland Basin on the next flood tide. By the early morning of Tuesday 8 September, the ship was anchored off "North Joggin", the centre of the grindstone trade at present-day Rockport, New Brunswick ( $\left.45^{\circ} 43^{\prime} 59 \mathrm{~N}, 64^{\circ} 29^{\prime} 37 \mathrm{~W}\right)$. Here, some of the party briefly rowed ashore to buy supplies of fresh milk while others took time to examine the grindstone quarries.

"After breakfast the vessel dropped over to South Joggin" (Hopkins 1835a, p. 453) on the Nova Scotian side of Chignecto Bay to explore the Pennsylvanian coal-bearing strata (FalconLang et al. 2006). Although the geology of this locality had only recently been elucidated (Brown and Smith 1829), coal had been mined there since at least 1686, if not earlier (Falcon-
Lang 2006, 2009). From the ship, Hopkins (1835a) described the Joggins section as follows: "The lofty sea wall rising, perpendicular, 100, and in places, perhaps, 150 feet, is striated by lines, drawn with mathematical precision, inclining to the horizon at an angle of about $30 \mathrm{deg}$. These lines separate the shale, coal and gray wacke-slate [fissile shale], which form the body of the cliff" (p. 453). Oddly, in his sketch of the section, Emmons rendered the stratification back to front, dipping to the left, and suggesting it was drawn from memory (Fig. 9). Rowing ashore, the group investigated the area around Bell's Brook $\left(45^{\circ} 41^{\prime} 38 \mathrm{~N}, 64^{\circ} 27^{\prime} 02 \mathrm{~W}\right)$, noting that "one deposit of bituminous coal, four feet thick" (the Joggins Seam) was being mined on a small scale (Falcon-Lang 2009).

Most exciting for the group was the prospect of seeing the upright fossil trees alluded to by Brown and Smith (1829), and described by Gesner during their meeting a week earlier. Just as they discovered one of these fossil trees embedded in the cliff, wrote Hopkins (1835a), "who should we have the pleasure of seeing but the Dr. [Gesner] himself - accoutred in his mineralizing dress" (p. 453). He had ridden on his black horse from Parrsboro "about 30 miles across the country to meet" them. Emmons assigned the fossil tree to "the order sigillariae" and noted its resemblance to "a fluted column" (Emmons 1836, p. 339). In a dangerous exercise, "by pecking a series of steps out of the side of the cliff", the group "succeeded in getting sufficiently high to loosen the tree" (Hopkins 1835a, p. 454). The party narrowly escaped injury when the fossil tree suddenly slipped down through its own bark and triggered a rock fall - an incident alluded to in Gesner's (1836) book on the geology of Nova Scotia.

One major scientific opportunity was missed during the party's three days of fossil collecting at Joggins: the identification of the stigmarian roots of the sigillarian trees. Although several fine specimens of Phytolithus verrucosus (Stigmaria of current nomenclature) were located and Hopkins (1835a, p. 454) noted their resemblance to "the root of an aquatic" plant, their connection to Sigillaria was not recognized. As Emmons (1836) noted, when an upright Sigillaria tree was examined, "the lower portion of the trunk... was broken away... [so] there were no appearance of roots" (p. 339). Four years later, Brongniart (1839) proposed the identity of Stigmaria and Sigillaria based on similar anatomy and on 17 May 1841, the discovery of a Sigillaria with attached Stigmaria was announced in Britain (King 1843). This combined with the nearsynchronous recognition that the underclays of most coals contained Stigmaria (Logan 1840) represented a huge leap forward in the understanding of coal formation. For the first time, it became clear that coal originated as a peaty soil beneath a lycopsid forest, rather than as a transported log jam a hypothesis earlier favoured by Lyell (1830-33). When Lyell (1843) visited Joggins at the culmination of this exciting period in July 1842, he found many examples of Stigmaria connected to Sigillaria and rooted in coal - hence it is perhaps surprising that the Williams College group failed to make this observation, and missed the opportunity to solve the then knotty problem of the origin of coal. 


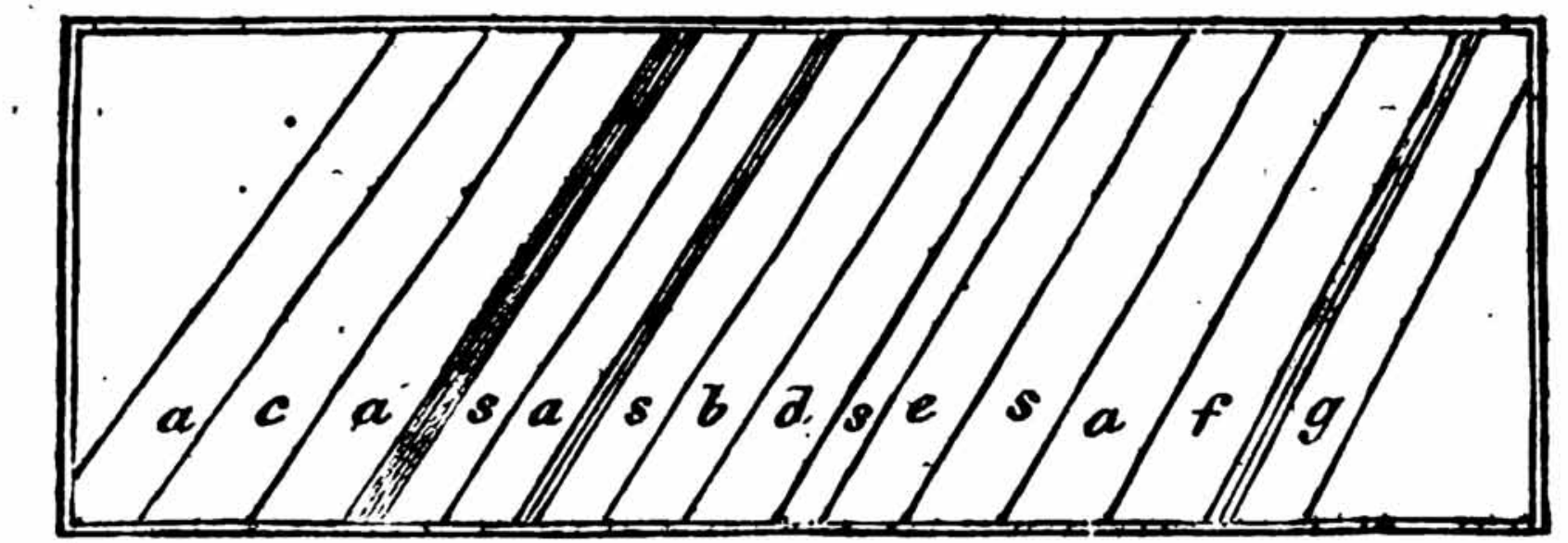

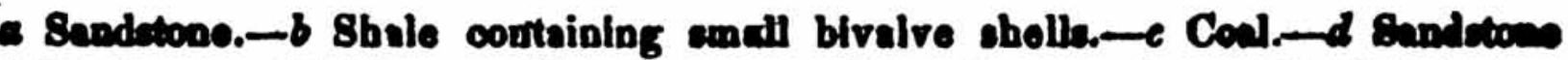
and Lignito. - e Nodular argillaceons Iron. $-f$ Argillaceous Iron with Lignites. $\boldsymbol{\varepsilon}$ Thin layers of coal. $\rightarrow$ Shale.

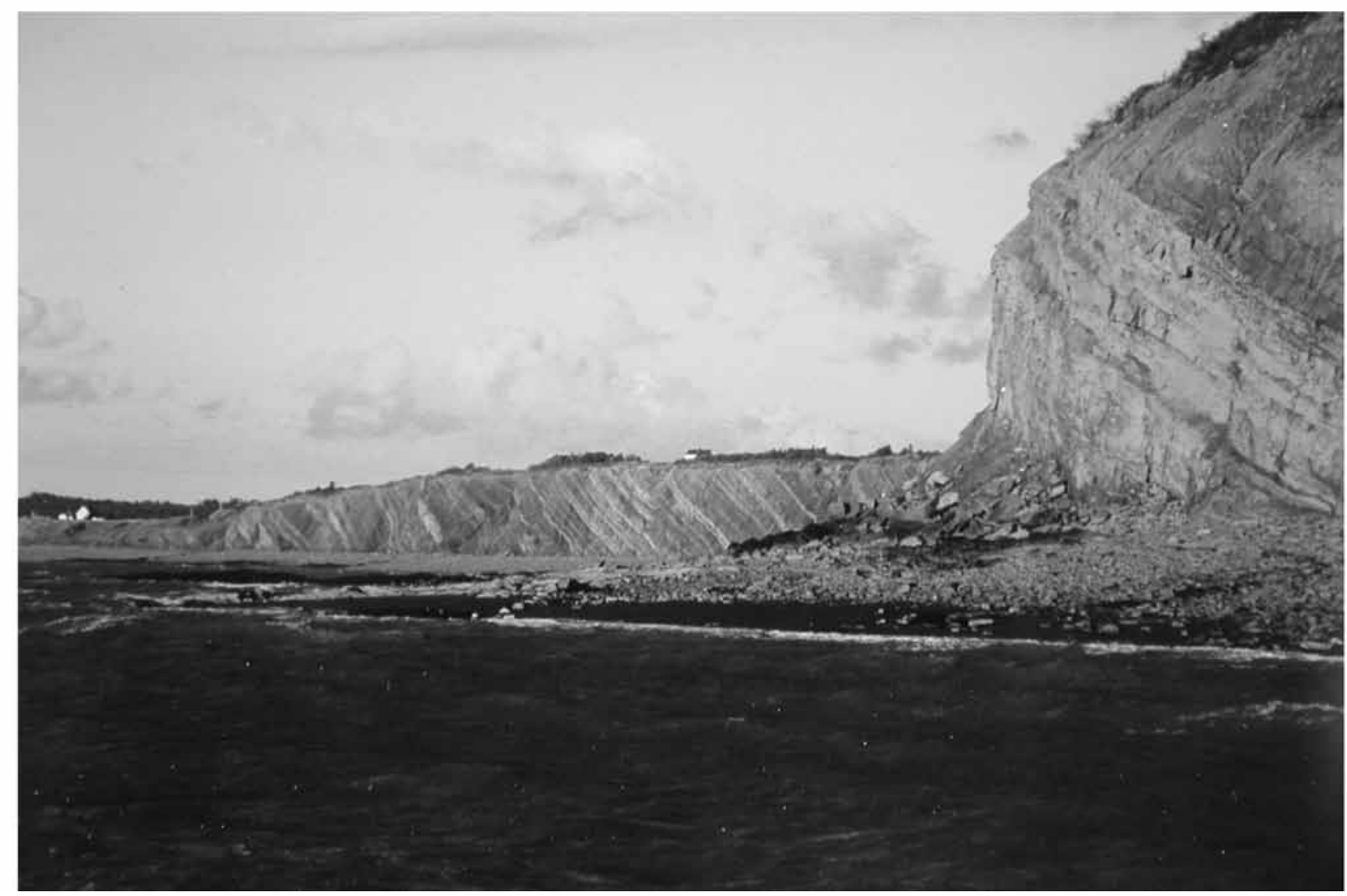

Fig. 9. Coal measure strata, near Joggins, Nova Scotia. Above, a sketch by Emmons: Note that the strata are curiously backto-front (after Emmons 1836, p. 339). Below, a modern photograph of the cliff-section (courtesy of Mike Rygel). 


\section{FOSSIL TREE ON GRINDSTONE ISLAND}

Towards the end of the week, on Friday 11 September, the William College party crossed over to the northwest shore of Chignecto Bay and landed at Grindstone Island, New Brunswick $\left(45^{\circ} 43^{\prime} 29 \mathrm{~N}, 65^{\circ} 36^{\prime} 56 \mathrm{~W}\right)$. As its name suggests, this island had been a source of grindstones, in fact since the first decade of the Eighteenth Century. But by 1835, quarrying had been relocated to more accessible sites at Sackville, Rockport, Joggins, and Apple River (Falcon-Lang 2009). On Grindstone Island, the economic sandstone beds belong to the Pennsylvanian braided-fluvial succession of the Boss Point Formation (Plint and Browne 1994).

While rowing round the western side of the island, Emmons spotted a very large fossil tree trunk, sub-horizontal within a channel sandstone, about $8 \mathrm{~m}$ above "the base of the cliff" (Emmons 1836, p. 340). The trunk was "uncovered for about forty feet $[12 \mathrm{~m}]$, and probably twenty feet [6 $\mathrm{m}]$ towards its base is yet concealed in the rock and debris". In addition, "some obscure appearances of branches" were evident at one end (Emmons 1836, p. 340). On return from the excursion, Emmons studied the calcite-permineralized wood and other anatomically preserved plants from Joggins using thin sections, a revolutionary technique developed by William Nicols (17681851) in 1828 (Young 2003), and only once before applied to fossils - by Henry Witham (1779-1844), as he outlined in his landmark book, Observations on Fossil Vegetables (Witham 1831). Emmons' analysis likely inspired the work of William Dawson (1820-1899), who first visited Joggins as a schoolboy in 1835 (Dawson 1901) and later undertook systematic studies of Pennsylvanian permineralized plants from Nova Scotia (Falcon-Lang and Calder 2005).

In his study of the Grindstone Island tree, Emmons (1836) described the fossil wood anatomy, correctly compared it with a similar Pennsylvanian tree found at Wideopen Quarry, near Newcastle in England (Witham 1831), and pronounced it to be the trunk of "a coniferous plant" (p. 342). Many such trunks, now assigned to a sister group of the true conifers (cordaitalians), have been discovered in the Boss Point Formation of Nova Scotia and New Brunswick (Falcon-Lang and Bashforth 2005). Of even greater importance, Emmons illustrated the fact that the Grindstone Island trunk lacked tree-rings (Fig. 10), implying it grew in environments "similar to those of tropical climates", as pointed out by many other geological writers at that time (Emmons 1836, p. 340).

But how was this paleoclimatic inference to be reconciled with the present mid-latitude position? Hopkins (1835a) summarized some of the possibilities. First, he ruled out the possibility that the fossil trees had been transported by ocean currents from tropical climates to Maritime Canada. While the Gulf Stream passed close to the shores of Nova Scotia, at least some of the fossil trees were preserved in growth position and therefore originated where they now stood (Hopkins 1835a). Hence one "very bold theory" was that "the equator then must have" passed through Maritime Canada in the Pennsylvanian. However, this necessitated "a shogging of the

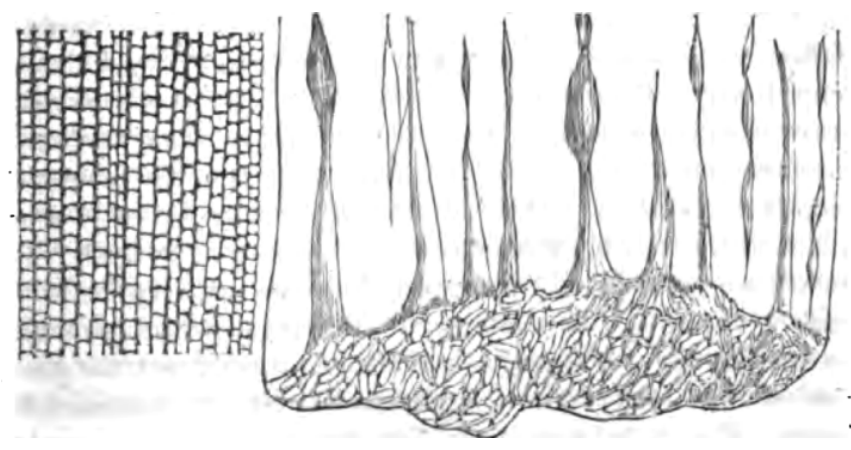

Fig. 10. Anatomically preserved fossil plants from Joggins (right) and Grindstone Island (left). Note that the fossil wood from Grindstone Island lacks tree-rings, implying a tropical climate (Emmons 1836, p. 341).

earth's axis... $40 \mathrm{deg}$. out of place" which is "a pretty serious business" (Hopkins 1835a, p. 454). An alternative possibility, argued Hopkins (1835a), was that tropical climates had once extended up into mid-latitudes. This was a position he thought that "Dr. Hutton would allow" - a reference to James Hutton (1726-1797), who was an early proponent of climate change through geologic time (Hopkins 1835a, p. 454). What, of course, Hopkins was quite unable to conceive was the notion that Joggins had drifted north to its present position from the tropics due to plate tectonics and consequent "continental drift".

\section{HOMEWARD BOUND}

Following a productive week examining the Coal Measures of the Cumberland Basin, the party commenced their long homeward journey on Saturday 12 September. Travelling down the Bay of Fundy close to the New Brunswick coast, they paused that morning at Martin Head $\left(45^{\circ} 29^{\prime} 33 \mathrm{~N}, 65^{\circ} 12^{\prime} 02 \mathrm{~W}\right)$ to examine a small outcrop of red beds, now known to be of Triassic age and assigned to the Fundy Group. Although pioneering palaeobotanist Ruth Holden (1890-1917) made significant discoveries of anatomically preserved plants at this remote site in the early twentieth century (Holden 1913), the Williams College party overlooked this material despite examining the strata "with some care" (Hopkins 1835a, p. 344). Proceeding farther, in the late afternoon, Captain Hallett anchored the Flight just off Quaco Head, near St. Martins $\left(45^{\circ} 19^{\prime} 29 \mathrm{~N}, 65^{\circ} 32^{\prime} 03 \mathrm{~W}\right)$. From onboard ship, they observed "a thin stratum of sandstone... resting unconformably... on talcose slate", probably a reference to the unconformity between Mississippian strata and the Precambrian Coldbrook Group (Jutras et al. 2007).

After resting on Sunday 13 September, the group then sailed back to the southeast shore of the Bay of Fundy and spent the next two days further exploring the North Mountain Basalt at Digby $\left(44^{\circ} 37^{\prime} 19 \mathrm{~N}, 65^{\circ} 45^{\prime} 27 \mathrm{~W}\right)$ and in the surrounding Annapolis Basin. On Wednesday 16 September, they entered Saint Mary's Bay in the southwest extremity of Nova Scotia and 
examined the basalt further at Gulliver's Hole $\left(44^{\circ} 29^{\prime} 34 \mathrm{~N}\right.$, $\left.65^{\circ} 57^{\prime} 01 \mathrm{~W}\right)$ and Sandy Hole $\left(44^{\circ} 29^{\prime} 18 \mathrm{~N}, 66^{\circ} 05^{\prime} 26 \mathrm{~W}\right)$. None of these exploits are recorded in detail in any of the journals that have survived. Although an excursion to the island of Grand Manan ( $\left.44^{\circ} 43^{\prime} 48 \mathrm{~N}, 66^{\circ} 47^{\prime} 43 \mathrm{~W}\right)$ had been proposed, this was abandoned "for want of time" (Hopkins 1835a, p. $455)$ and, on Thursday 17 September, they returned to Lubec on the border with Maine to comply with United States customs regulations. Departing after lunch on 18 September, a journey of two days then brought them home to Boston on the morning of Sunday 20 September 1835, completing almost four weeks at sea.

\section{A PLACE IN HISTORY}

This Williams College expedition has an important place in the history of geology. It was the first geological excursion undertaken by a North American college and helped establish fieldwork as a key part of the natural science curriculum (Chadbourne 1877). As Hopkins (1835a) noted, "tours, for the gratification of a scientific curiosity, will we think, rather further the true ends of a liberal education" (p. 455). However, in the early Nineteenth Century, relatively few geologists used fieldwork as a means of training students, and when they did so, it was on an informal basis. For example, at the University of Cambridge, Adam Sedgewick (1785-1873) would "sometimes give a field lecture, taking some select philo-geologists on a pedestrian excursion, a few miles in the country" (Anon 1824, p. 114). Famously, he also gave one-to-one field tuition to the young Charles Darwin in 1831 while mapping in Wales (Herbert 2005) - and at the time of the Williams College Expedition, Darwin was, of course, engaged in his own voyage of discovery, arriving on the Galapagos Islands on 15 September 1835.

Formal fieldwork programmes did not emerge until the midNineteenth Century - and even then, never with the ambition of the Williams College excursion. In 1840, geology courses at the University of Durham in England contained "occasional surveying excursions, in the field and underground" (Buckland 1840, p. 217). In 1847, the Rensselaer Polytechnic Institute of New York State was offering courses in geology "pursued through the direct examination of specimens from the cabinets, or those derived immediately from the field" (Anon 1847, p. 174). From 1854, John Morris (1810-1886), professor at University College London, ran a popular program of "practical field lessons" through southern England (Morris 1868, p. 233), and at the California Academy of Science field excursions were commonplace in 1867 (Anon 1868). Nevertheless, all these opportunities postdate the 1835 field expedition of Williams College, some by a considerable margin.

The Williams College expedition to Maine, New Brunswick and Nova Scotia therefore stands as one of the earliest geological field trips arranged for an undergraduate student body, and "the first student expedition in the annals of American Science" (Rudolph 1957, p. 150). As W. John Nelson notes (written communication 2009), "this trip was the ancestor of summer geological field camps, now a standard feature of most United States undergraduate programs." But it poses the question, "why didn't similar field courses rapidly catch on at other schools after the Williams experience?" The main reason was probably the logistical difficulties of running field classes, which needed large amounts of money and motivation to overcome. In addition, in the absence of extensive road/rail cuttings and mines (in North America at least), outcrop was limited to coastal cliffs and necessitated exploration by boat.

Sadly, our knowledge of the Williams College Expedition is limited to the various published accounts (Hopkins 1835a, 1835b, Emmons 1836, Perry 1899) because a fire on 17 October 1841 destroyed all documentation concerning the trip and almost all the fossil and mineral collections belonging to the Lyceum (Anon. 1852, 1885; Rogers 1855). Nevertheless, the rich surviving accounts paint a vivid picture of the challenges and opportunities of geological fieldwork in the early Nineteenth Century.

\section{ACKNOWLEDGEMENTS}

HFL acknowledges a Natural Environment Research Council Advanced Fellowship (NE/F014120/2) and thanks Linda Hall, one of the archivists of Williams College, Massachusetts, for kind help in locating and reproducing manuscripts used in this study; she also supplied the images used in Figures 1 and 2. Mike Rygel kindly supplied the image of Joggins in Figure 9. This paper benefited from the thoughtful reviews of W. John Nelson (Illinois Geological Survey) and Randall Miller (Saint John Museum) and the meticulous editorial work of Rob Fensome.

\section{REFERENCES}

Adam, W. 1857. First lessons in geology: with a special article on the toadstones of Derbyshire. J. \& C. Mozley, London. $173 \mathrm{p}$.

Anon. 1824. The Cambridge lecturers. Knight's Quarterly Magazine, 3, pp. 112-116.

Anon. 1847. The farmer's notebook. The Cultivator, 4. 174 p.

Anon. 1852. Catalogue of the Lyceum of Natural History of Williams College. Published by the Society, Williamstown, Massachusetts. $58 \mathrm{p}$.

Anon. 1859. Collections of the Maine Historical Society. Volume 6. Published by the Society. 254 p.

Anon. 1868. Regular Meeting, May 6, 1867. Proceedings of the California Academy of Natural Sciences, 3, pp. 352-353.

Anon. 1885. Semi-centennial of the Lyceum of Natural History at Williams College. Science, 5, pp. 385-386. doi:10.1126/ science.ns-5.118.385

Anon. 1915. Williams College celebrates. New York Times, 2 May $1915.7 \mathrm{p}$. 
Anon. 1982. Captain Bangs Hallett (1807-1893). Pamphlet published by the Historical Society of Old Yarmouth. 4 p.

Atlantic Geoscience Society. 2001. The Last Billion Years: a geological history of the Maritime Provinces of Canada. Atlantic Geoscience Society and Nimbus Publishing, Halifax. 212 p.

Bennett, J. 2007. The geology of Atlantic Canada: in the footsteps of Charles Lyell. Geologists' Association Magazine, 6, pp. 11-13.

Bertram, G.T., Emery, D., and Myers, K. 1996. Sequence stratigraphy. Blackwell Science, Oxford. 304 p.

Brongniart, A.T. 1839. Observations sur la structure intérieure du Sigillaria elegans comparée à celle des Lepidodendron et des Stigmaria et à celle des végétaux vivants. Archives du Museum d'Histoire Naturelle, 1, pp. 405-461.

Brown R., and Smith, R. 1829. Geology and mineralogy. In An historical and statistical account of Nova Scotia, volume 2. Edited by T.C. Haliburton. Joseph Howe, Halifax, pp. 414-453.

Brush, S.G. 1996. A history of modern planetary physics: nebulous Earth. Cambridge University Press. 324 p.

Buckland, W. 1840. Anniversary address. Proceedings of the Geological Society of London, 3, pp. 210-248.

Chadbourne, P.A. 1877. The hope of the righteous: discourses at the funerals of Albert Hopkins, Nahum Gale, and N.H. Griffin. G.P. Putnam \& Sons, New York. 60 p.

Dawson, J.W. 1868. Acadian geology. The geological structure, organic remains, and mineral resources of Nova Scotia, New Brunswick, and Prince Edward Island. 2nd edition. MacMillan \& Co, London. 694 p.

Dawson, J.W. 1901. Fifty years of work in Canada, scientific and educational. Hanson \& Co, London. $324 \mathrm{p}$.

Dorion, C.C., Balco, G.A., Kaplan, M.R., Kreutz, K.J., Wright, J.D., and Borns, H.W., Jr. 2001. Stratigraphy, paleoceanography, chronology, and environment during deglaciation of eastern Maine. In Deglacial history and relative sea-level changes, northern New England and adjacent Canada. Edited by T.K. Weddle and M.J. Retelle. Geological Society of America, Special Paper 351, pp. 215-242.

Durfee, C. 1860. A History of Williams College. A. Williams, Boston. 432 p.

Emmons, E. 1836. Notice of a scientific expedition. American Journal of Arts and Sciences, 30, pp. 330-354.

Falcon-Lang, H.J. 2006. A history of research at the Joggins Fossil Cliffs, the world's finest Pennsylvanian section. Proceedings of the Geologists' Association, 117, pp. 377-392.

Falcon-Lang, H.J. 2008. Joggins Fossil Cliffs receive UNESCO World Heritage Status. Geology Today, 24, pp. 12.

Falcon-Lang, H.J. 2009. The earliest history of coal mining and grindstone quarrying at Joggins, Nova Scotia and its implications for the meaning of the place-name "Joggins". Atlantic Geology, 45, pp. 1-21.

Falcon-Lang, H.J., and Bashforth, A.R. 2005. Morphology, anatomy, and upland ecology of large cordaitalean trees from the Middle Pennsylvanian of Newfoundland. Re- view of Palaeobotany and Palynology, 135, pp. 223-243. doi:10.1016/j.revpalbo.2005.04.001

Falcon-Lang, H.J., and Calder, J.H. 2005. Sir William Dawson (1820-1899): a very modern palaeobotantist. Atlantic Geology, 41, pp. 103-114.

Falcon-Lang, H.J., Benton, M.J., Braddy, S.J., and Davies, S.J. 2006. The Pennsylvanian tropical biome reconstructed from the Joggins Formation of Canada. Journal of the Geological Society, 163, pp. 561-576. doi:10.1144/0016764905-063

Fenton, C.L. 1969. The Story of the great geologists. Ayer Publishing, Boston. 301 pp.

Fleming, K., Johnston, P., Zwartz, D., Yokoyama, Y., Lambeck, K., and Chappell, J. 1998. Refining the eustatic sea-level curve since the Last Glacial Maximum using far- and intermediate-field sites. Earth and Planetary Science Letters, 163, pp. 327-342. doi:10.1016/S0012-821X(98)00198-8

Fowell, S.J., and Traverse, A. 1995. Late Triassic palynology of the Fundy Basin, Nova Scotia and New Brunswick. Review of Palaeobotany and Palynology, 86, pp. 211-233. doi:10.1016/0034-6667(94)00147-C

Friedman, G.M. 2006. Ebenezer Emmons (1799-1863), founder of American Paleozoic stratigraphy: hero of the Taconic controversy, one of the most celebrated geological disputes in North America. Earth Sciences History, 25, pp. 225-238.

Gates, O. 1975. Geologic map and cross sections of the Eastport quadrangle, Maine. Maine Geological Survey, Geologic Map Series GM-3, 19 p., map, scale 1:48 000.

Gesner, A. 1836. Remarks on the geology and mineralogy of Nova Scotia. Gossip \& Coade, Halifax. 339 p.

Gesner, A. 1842. Synopsis of the contents of Gesner's Museum of Natural History at Saint John, New Brunswick: opened on the fifth day of April, 1842. Henry Chubb, Saint John. 48 p.

Gesner, A. 1843. A geological map of Nova Scotia, with an accompanying memoir. Proceedings of the Geological Society of London, 4, pp. 186-190.

Gesner, A. 1849. The industrial resources of Nova Scotia. A.C. MacKinlay, Halifax. 341 p.

Herbert, S. 2005. Charles Darwin, geologist. Cornell University Press, Ithaca. $512 \mathrm{p}$.

Hineline, M. 1988. Charles Thomas Jackson and the first geological survey of Maine, 1836-1838. In Studies in Maine geology, Volume 1: Structure and stratigraphy. Edited by R.D. Tucker and R.G. Marvinney. Maine Geological Survey, pp. 1-16.

Holden, R. 1913. Some fossil plants from eastern Canada. Annals of Botany, 27, pp. 243-255.

Hon, R., Fitzgerald, J.P., Sargent, S.L., Schwartz, W.D., Dostal, J., and Keppie, J.D. 1992. Silurian-Early Devonian mafic rocks of the Piscataquis Volcanic Belt in northern Maine. Atlantic Geology, 28, pp. 163-170.

Hopkins, A. 1835a. Scientific expedition of students of Williams College, from Boston along the eastern coast to St. 
Johns, N.B. and Halifax and Windsor, N.S. The Monthly Traveller, 6, pp. 445-455 (13 October 1835, Boston).

Hopkins, A. 1835b. Scientific expedition of students of Williams College, from Boston along the eastern coast to St. Johns, N.B. and Halifax and Windsor, N.S. The American Traveller (13, 17 and 20 November 1835, Boston).

Horn, M. 1999. Academic freedom in Canada: a history. University of Toronto Press. $446 \mathrm{p}$.

Jackson, C.T. 1839. Third report on the geology of the State of Maine. 2 volumes. Smith \& Robinson, Augusta. 128 p.

Jackson, C.T., and Alger, F. 1828. A description of the mineralogy and geology of a part of Nova Scotia. American Journal of Science and Arts, 14, pp. 305-330.

Jackson, C.T., and Alger, F. 1829. A description of the mineralogy and geology of a part of Nova Scotia. American Journal of Science and Arts, 15, pp. 132-160.

Jackson, C.T., and Alger, F. 1832. Remarks on the mineralogy and geology of Nova Scotia. E.W. Metcalfe \& Company, Cambridge. $116 \mathrm{p}$.

Johnson, R. 2004. The rise and fall of the Boston Society of Natural History. Northeastern Naturalist, 11, pp. 81-108. doi:10.1656/1092-6194(2004)011[0081:TRAFOT]2.0.CO;2

Jourdan, F., Marzoli, P., Bertrand, H., Cirilli, S., Tanner, L.H., Kontak, D.J, McHone, G., Renne, P.R., and Bellieni. G. 2009. ${ }^{40} \mathrm{Ar} /{ }^{39} \mathrm{Ar}$ ages of CAMP in North America: implications for the Triassic-Jurassic boundary and the ${ }^{40} \mathrm{~K}$ decay constant bias. Lithos, 110, pp. 167-180. doi:10.1016/j.lithos.2008.12.011

Jutras, P., Utting, J., and McLeod, J. 2007. Link between long-lasting evaporitic basins and the development of thick and massive phreatic calcrete hardpans in the Mississippian Windsor and Percé groups of eastern Canada. Sedimentary Geology, 201, pp. 75-92. doi:10.1016/j.sedgeo.2007.04.008

King, W. 1843. On Sigillaria, Stigmaria and Neuropteris. The New Edinburgh Philosophical Journal, 35, pp. 372-375.

Kontak, D.J. 2008. On the edge of CAMP: geology and volcanology of the Jurassic North Mountain Basalt, Nova Scotia. Lithos, 101, pp. 74-101.

Lewis, R.C., 1993. Williams 1793-1993, a pictorial history. Williams College. Bicentennial Commission, Williamstown, Massachusetts. 279 p.

Logan, W.E. 1840. On the character of the beds of clay lying immediately below the coal seams of south Wales. Proceedings of the Geological Society of London. 3, pp. 275-277.

Lyell, C. 1830-1833. Principles of geology. 3 volumes. John Murray, London.

Lyell, C. 1843. On the upright fossil-trees found at different levels in the coal strata of Cumberland, Nova Scotia. Proceedings of the Geological Society, London, 4, pp. 176-178.

Mackay W. 1834. Belcher's map of the Province of Nova Scotia, including the Island of Cape Breton. John Snow, London.

McAllister, E.M. 1941. Amos Eaton: scientist and educator, 1776-1842. Humphrey Milford Press, Oxford. 592 p.

McLeod, G.D. 1891. Stories from the Land of Evangeline. McClelland and Stewart, Toronto. $341 \mathrm{p}$.
Mellen, G. 1843. A book of the United States: exhibiting its geography, divisions, constitution, and government: and presenting a view of the republic generally, and of the individual states: together with a condensed history of the land, from its first discovery to the present time. Sumner \& Goodman, Hartford. 847 p.

Mertz, K.A., Jr., and Hubert, J.F. 1990. Cycles of sandflat/playalacustrine mudstone in the Triassac-Jurassic Blomidon redbeds, Fundy rift basin, Nova Scotia: implications for climatic and tectonic controls. Canadian Journal of Earth Science, 27, pp. 442-451.

Miller, R.F. 2001. History of geological investigation of Saint John, New Brunswick. New England Intercollegiate Field Conference, Excursion C1, 15 p.

Miller, R.F. 2008. Geotourism in Saint John, New Brunswick. Atlantic Geology, 44, 27 p.

Miller, R.F. and Buhay, D.N. 2007. Gesner's Museum of Natural History, an early Canadian geological collection. Geoscience Canada, 34, pp. 37-48.

Morris, J. 1868. Geological excursion to Bath. Geological Magazine, 5, 233-236.

Murdoch, B. 1865. A history of Nova-Scotia, or Acadie. J. Barnes, Halifax. 628 p.

Perry, A.L. 1899. Williamstown and Williams College. Published by the Author, Williamstown, pp. 565-573.

Plint, A.G., and Browne, G.H. 1994. Tectonic event stratigraphy in a fluvio-lacustrine, strike-slip setting: the Boss Point Formation (Westphalian A), Cumberland Basin, Maritime Canada. Journal of Sedimentary Research, B64, pp. 341364.

Rogers, W.B. 1855. Address before the Lyceum of Natural History of Williams College, August 14, 1855. T.R. Marvin \& Son, Boston. 34 p.

Rowe, D.J. 1983. Lead manufacturing in Britain: a history. Taylor \& Francis, London. 427 p.

Rudolph, F. 1957. Mark Hopkins and the Log: Williams College 1836-1872. Yale Historical Publications, Miscellany, 63, $267 \mathrm{p}$.

Russell, L.S. 1976. Gesner, Abraham. In Dictionary of Canadian biography, Volume IX, 1861-1870. Edited by W.B. George, J. Hamelin, J., and F.G. Halpenny, University of Toronto Press, pp. 308-312.

Scobie, C.H.H., and Grant, J.W. 1992. The contribution of Methodism to Atlantic Canada. McGill-Queen's Press, Montreal. $281 \mathrm{p}$.

Smallwood, W.M. 1937. The Williams Lyceum of Natural History, 1835-1888. The New England Quarterly, 10, pp. 553557.

van Staal, C.R., Dewey, J.F., MacNiocal, L., and McKerrow, W.S. 1998. The Cambrian-Silurian tectonic evolution of the northern Appalachians and British Caledonides: history of a complex, west and southwest Pacific-type segment of Iapetus. In Lyell, The Past is the Key to the Present. Edited by D.J. Blundell and A.C. Scott, Geological Society, London, Special Publications 143, pp. 199-242.

von Bitter, P.H. 1977. Abraham Gesner (1797-1864), an early 
Canadian geologist - charges of plagiarism. Geoscience Canada, 4, pp. 97-100.

von Bitter, P.H. 1978. Charles Jackson M.D. (1805-1880) and

Francis Alger (1807-1863). Geoscience Canada, 5, pp. 7982.

Warren, J.C. 1853. Address to the Boston Society of Natural History. J. Wilson \& Son. 48 p.

Wells, D.A., and Davis, S.H. 1847. Sketches of Williams College. H.S. Taylor, Williamstown. 99 p.

Witham, H.TM. 1831. Observations on fossil vegetables. Blackwood and Cadell, Edinburgh and London, UK. 48 p. Wolfe, R.J. 2007. Charles Thomas Jackson, "the head behind the hands": applying science to implement discovery and invention in early Nineteenth Century America. Norman Publishing, California. $417 \mathrm{p}$.

Wosh, P.J. 1994. Spreading the Word: the Bible business is Nineteenth Century North America. Cornell University Press, Ithaca. $271 \mathrm{p}$.

Wright, H.E. and Miller, R.F. 1990. Robert Foulis (17961866): New Brunswick inventor, entrepreneur and geologist. Geoscience Canada, 17, pp. 101-104.

Young, D.A. 2003. Mind over magma: the story of igneous petrology. Princeton University Press. 686 p.

Editorial responsibility: Robert A. Fensome 